\title{
Svalbard Takımadası ve Çevresindeki Deniz Alanlarına Yönelik Uluslararası Hukuk Düzenlemelerinin İ́rdelenmesi ${ }^{1}$
}

\author{
Analysis of International Legal Regulations in the Maritime Zone Around \\ Svalbard Archipelago
}

Ceren UYSAL OĞUZ²

Güneş ERSOY ${ }^{3}$

Geliş tarihi: 31.05.2019, Kabul tarihi: 29.07.2019, Basım tarihi: 25.10.2019

\section{Öz}

Arktika Bölgesi ve bu bölgede yer alan Svalbard Takımadası, bölgedeki potansiyel enerji kaynakları, iklim değişikliğinin etkileri, yeni deniz yolları ve deniz yetki alanları üzerindeki tartışmalar nedeniyle küresel ve bölgesel güçlerin politik ve ekonomik gündeminde yer almaktadır. 1920 tarihli Svalbard Antlaşması ve uluslararası deniz hukuku sözleşmelerinin farklı zamanlarda imzalanması, Norveç'in ve diğer akit tarafların Antlaşma'yı farklı yorumlamalarına neden olmaktadır. Bu durum Takımada çevresindeki deniz yetki alanlarına yönelik akit taraflar arasında hukuki anlaşmazlıklar yaratmaktadır. Norveç tarafindan hak iddia edilen Svalbard kıta sahanlığ1 ve ilan edilen Balıkçlık Koruma Bölgesi anlaşmazlıkların temel nedenleriyken, bölgedeki kota düzenlemeleri ve buna yönelik Norveç yaptırımları anlaşmazlıkları artırıcı rol oynamaktadır. Çalışsmada, uluslararası deniz hukuku sözleşmeleri ve kavramları Svalbard özelinde ele alınmış ve hukuki anlaşmazlıklar neden-sonuç ilişkisi içerisinde ortaya koyulmuştur.

Anahtar Kelimeler: Svalbard Antlasması, münhasir ekonomik bölge, kita sahanhĭğ, Birlesmis Milletler Deniz Hukuku Sözllesmesi, ayrmollk yasağz ve mutlak esittlik

Jel Kodlart: F53, K33, Q22

\begin{abstract}
The Arctic Region and the Svalbard Archipelago located in the Arctic have become one of the focal points of political and economic agenda of global and regional powers due to potential energy resources, impacts of climate change, new maritime routes and issues over maritime jurisdiction. Signing of the 1920 Svalbard Treaty and international conventions on the law of the sea at different times let Norway and other contracting parties to interpret the Svalbard Treaty differently. It

\footnotetext{
${ }^{1}$ Bu çalışma, Güneş Ersoy’un Akdeniz Üniversitesi Sosyal Bilimler Enstitüsü Uluslararası İlişkiler Anabilim Dalı'nda savunmuş olduğu "Uluslararası İlişkilerde Spitsbergen Takımadaları: Balıkçılık Koruma Bölgesi ve Kıta Sahanlığı Üzerindeki Hukuki ve Politik Anlaşmazlıklar" başıklı Yüksek Lisans tezinden yola çıkarak hazırlanmıştır.

2 Akdeniz Üniversitesi, İIBF Uluslararası İlişkiler Bölümü, Dr. Öğr. Üyesi, cuysaloguz@akdeniz.edu.tr https:// orcid.org/0000-0001-7342-0362

3 Akdeniz Üniversitesi, İIBF Uluslararası İlişkiler Bölümü, Doktora öğrencisi, gunesersoy@windowslive.com

https://orcid.org/0000-0001-5445-5674
} 
creates legal disputes between the contracting parties on maritime jurisdiction around the archipelago. While Norway's claim on the Svalbard continental shelf and declared fisheries protection zone are the main causes of disputes, fishing quota regulations and Norwegian sanctions against contracting parties also increase the tension in the region. In this study, conventions on the law of the sea and their notions are discussed in the case of Svalbard; and legal disputes are examined in the context of cause and effect relation.

Keywords: Svalbard Treaty, fisheries protection zone, continental shelf, United Nations Convention on the Law of the Sea, non-discrimination and equality of treatment

Jel Codes: F53, K33, Q22

\section{Giriş}

Arktika Bölgesi'nin iklimsel, coğrafi ve siyasi açılardan çeşitli tanımları yapılmaktadır. İklimsel olarak, Kutup ağaç sınırının kuzeyinde kalan, genel olarak permafrost tabakasıly kaplı ve günlük ortalama yaz sıcaklığının 10 ${ }^{\circ}$ C’nin üzerine çıkmadığı yüksek enlemleri içermektedir (NSIDC, 2019). Coğrafi açıdan, 66 33" Kuzey enlemi ile Kuzey Kutup Noktasi arasında kalan, yaklaşı 8 milyon $\mathrm{km}^{2}$ 'lik kara parçasını ve 18 milyon $\mathrm{km}^{2}$ 'lik deniz alanını kapsayan dünyanın en kuzeyindeki alan olarak kabul edilmektedir (Spohr vd., 2013: 11). Arktika Bölgesi'nin siyasi tanımı ise Kuzey Kutup Bölgesi'nde yer alan ve Arktika Konseyi'ne üye 8 ülke [Norveç, İsveç, Danimarka (Grönland ve Faroe Adaları ile birlikte), İlanda, Finlandiya, Rusya, ABD ve Kanada] ile ilişkilendirilmektedir. A8 ülkeleri olarak da bilinen bu ülkeler Kuzey Kutup Bölgesi’ne yönelik özellikle sürdürülebilir kalkınma ve çevre koruma konularında işbirliği, koordinasyon ve etkileşimi sağlamak amacıyla hükümetlerarası bir forum olan Arktika Konseyi'nde bir araya gelmektedirler (Arctic Council, 2018). Bir başka siyasi tanım ise Arktika Okyanusu'na dayandirılmaktadır. A5 ülkeleri olarak adlandırılan Norveç, Danimarka (Grönland aracılığıyla), Rusya, ABD ve Kanada'nın Arktika Okyanusu'nda ekonomik bölgeleri ve kıta sahanlıkları vardır.

Arktika Bölgesi potansiyel enerji kaynakları, iklim değişikliğinin etkileri, yeni deniz yolları, deniz yetki alanları üzerindeki tartışmalar ve benzeri nedenlerle küresel siyasetin ve ekonominin odak noktaları arasındadır. Bu bölgede yer alan Svalbard Takımadası, uluslararası bilimsel araştırmaların ve çalışmaların yapıldığı bir coğrafya olmasının yanı sıra çevresindeki potansiyel enerji kaynakları ve deniz yetki alanlarına yönelik tartışmalarla da hem bölge ülkelerinin hem de farklı coğrafyalarda yer alan ülkelerin gündeminde yer almaktadır. Svalbard Takımadası, Danimarka'ya bağlı Grönland ile Rusya'ya ait olan Franz Josef Land Takımadası arasında bulunmaktadır. $74^{\circ}-81^{\circ}$ Kuzey paralelleri ile $10^{\circ}-35^{\circ}$ Doğu meridyenleri arasında yer alan ve yaklaşık $61.022 \mathrm{~km}^{2}$ yüzölçümüne sahip olan Svalbard'ın büyük bölümü buz örtüsüyle kaplı, el değmemiş doğal alanlardır. Norveç Adalet ve Kamu 
Güvenliği Bakanlı̆̆1 tarafindan yayınlanan Svalbard Raporu'nda Takımada topraklarının \%65'inin, karasularının ise \%87'sinin koruma altında olduğu ifade edilmektedir. Svalbard'da ekonomik faaliyetlerin sürekli olarak yürütüldüğü ve insan yerleşimi olan sadece yedi merkez vardır. Takımada'nın nüfusu yaklaşık 2500'dür ve bunun \%56,9'u Norveçlilerden, geri kalanı ise Rus, Tay, İsveçli, Filipinli ve Ukraynalı başta olmak üzere yabancılardan oluşmaktadır. Yerleşik insan sayısının azlığ1 Svalbard'ı dünyada nüfus yoğunluğu en düşük yerlerden biri haline getirmiştir (Norwegian Ministry of Justice and Public Security, 2016: 13; CIA World Factbook, 2019).

Dünyadaki petrol, doğalgaz, kömür gibi yenilenemeyen enerji kaynaklarının hızla tükenmesi nedeniyle ülkeler günümüzde genelde Arktika Bölgesi özelde ise Svalbard Takımadası çevresindeki petrol ve doğalgaz rezervlerine yönelmektedirler. Yapılan araştırmalara göre, bu bölgedeki keşfedilmemiş enerji kaynaklarının üçte ikisinin Norveç Denizi'nde ve Barents Denizi'nde, yani Takımada çevresindeki deniz alanlarında olduğu tespit edilmiştir. Bu alan petrol ve doğalgaz gibi potansiyel enerji kaynaklarının yanı sıra, balık kaynakları açısından da hazine işlevi görmektedir. Atlantik morinası ve ringa gibi ticari açıdan önemli balık sahaları Svalbard çevresindeki 200 deniz mili sınırları içerisinde bulunmaktadır (Åtland ve Pedersen, 2008: 242). İklim değişikliği sonucu buzulların erimesiyle birlikte kuzeye göç eden balıklar da ülkelere daha önce ulaşılması zor alanlarda balıkçılık yapma imkânı sağlamaktadır.

Antarktika'nın aksine, Svalbard'da yapılan bilimsel araştırmalar ekonomik çıkarlara kıyasla ülkelerin ikincil önceliklerini oluşturmaktadır. Buna rağmen Takımada kendine özgü statüsü sayesinde Arktika bilimsel araştırmaları için günümüzde çok önemli bir merkeze dönüşmüştür. Svalbard'1n 'laboratuvarı ve bilim kenti' olarak bilinen Ny Ålesund'da Norveç, İsveç, Almanya, Fransa, İtalya, Japonya, Çin, Britanya, Hollanda, Güney Kore ve Hindistan'ın sürekli araştırma üsleri bulunmaktadır (Coates ve Holroyd, 2017: 217).

Küresel iklim değişikliği, potansiyel enerji kaynakları, yeni deniz yolları, bilimsel araştırmalar gibi nedenlerle son y1llarda stratejik önemi artan Svalbard Takımadası hukuki, siyasi ve ekonomik alanlarda uluslararası anlaşmazlıklara konu olmaktadır. Bu anlaşmazlıkların kaynağı 20. yüzyılın ortalarından itibaren uluslararası deniz hukukunda yaşanan gelişmelerin Takımada üzerindeki yansımalarıdır.

Bu çalışmada 1920 tarihli Svalbard Antlaşması'nın ve uluslararası deniz hukuku sözleşmelerinin (1958 tarihli Cenevre Sözleşmesi ve 1982 tarihli Birleşmiş Milletler Deniz Hukuku Sözleşmesi-BMDHS) farklı zaman dilimlerinde imzalanması nedeniyle oluşan yorum farklılıklarının Svalbard Takımadası özelinde incelenmesi amaçlanmaktadır. Çalışmada kapsamlı bir literatür taraması yapılmış ve ilgili uluslararası hukuk metinleri incelenmiştir. 
Bu bağlamda birinci bölümde, Svalbard Takımadası'nın keşif tarihi ve hukuki statüsünün gelişimi anlatılmıştır. İkinci bölümde kendine özgü bir yapısı olan Svalbard Antlaşması ele alınmıştır. Çalışmanın üçüncü bölümünde Takımada çevresindeki tartışmalı deniz yetki alanları ve ilgili kavramlar uluslararası deniz hukuku sözleşmeleri çerçevesinde ortaya koyulmuştur. Bu bağlamda, yalnızca münhasır ekonomik bölge-balıkçılık koruma bölgesi ve kita sahanlı̆̆ı kavramları incelenmiş, Antlaşma'nın Svalbard anakarası üzerindeki ve karasularındaki hükümleri çalışma kapsamı dışında birakılmıştır. Dördüncü bölümde ise, Svalbard Takımadası çevresindeki deniz alanlarında Norveç ve diğer aktörlerin faaliyetleri değerlendirilmiştir.

\section{Svalbard Takımadası'nın Tarihi ve Hukuki Statüsünün Belirlenmesi}

1596'da Hollandalı kâşif Willem Barentsz, Uzakdoğu'ya açılan KuzeyDoğu Geçidi'ni bulmak üzere çıktığ1 yolculukta Bear Adası ve Spitsbergen (Svalbard) Takımadası'na ulaşmıştır. ${ }^{4}$ Barentsz'in Takımada'yı keşfinden yedi y1l sonra, 1603'te İngiliz Henry Hudson tarafindan ziyaret edilen Svalbard, kısa sürede balina avcılarının istilasına uğramıştır. Hudson'ın Londra'ya döndüğ̈unde paylaştığ1 “'Takımada'yı çevreleyen sularda sayısız balinanın tembelce yüzdügü" bilgisi hızla yayılınca, Avrupalı balina avcılarının Svalbard'a yönelmesi çok sürmemiştir. Başlangıçta İngilizler ve Hollandalılar arasındaki rekabet, bir süre sonra iki tarafin bu coğrafyayı aralarında paylaşıp diğer ülkeleri buradan uzak tutma konusunda anlaşmalarıyla sonuçlanmıştır. Hollandalilar kuzeyde yer alan Magdalenfjorden'da, Smeerenburg adli bir balina av istasyonu kurmuşlar; İngilizler ise adaların güneyine yerleşmişlerdir. 1613'te Fransızların bölgede varlık göstermek için Takımada'ya ilk bayrak dikme girişimleri İngilizler tarafindan engellenmiştir. Ancak Fransızlanın Svalbard üzerindeki hedefleri son bulmamış, 1693'te bu kez Sorgfjord'da Fransızlar ve Hollandalılar arasında, tarihte en kuzey noktada yaşanan deniz savaşı gerçekleşmiştir. Bu savaş sonunda Fransızlar çok sayıda Hollandalıyı öldürüp, 13 balina gemisini ele geçirmişlerdir (Anderson, 2009a: 124-126). Dolayısıyla Svalbard'ın sunduğu ekonomik firsatlardan yararlanmak için farklı ulusların kendi aralarındaki mücadeleleri oldukça eski tarihlere uzanmaktadır.

17. yüzylldan itibaren başta Grönland balinası (bowhead whale) olmak üzere deniz ayısı, fok gibi deniz memelilerinin aşırı avlanması sonucunda Takımada'nın ekosistemi ilk büyük yıkımı yaşamıştır (Molenaar, 2012: 4).

\footnotetext{
${ }^{4}$ Spitsbergen, Takımada'nın en büyük adasına verilen isimdir ve uzun süre bu alanın tamamı için kullanılmıștır. Ancak 1920'li yıllarda Norveç, 12. yüzyıldan kalan kayıtlara dayanarak Takımada'nın ismini resmi olarak Svalbard şeklinde değiştirmiştir. Böylece ana ada Batı Spitsbergen'in ismi de Spitsbergen olarak kullanılmaya başlamıştır (Molenaar, 2012: 3-4). Bu makalede Takımada ve ilgili antlaşma için Svalbard ismi kullanılmıştır.
} 
Yüzyllar içerisinde sadece Svalbard ve çevresinde değil Arktika genelinde de yağları için avlanan balinaların sayıları hızla azalmıştır. 1610-1915 arasında Grönland balinalarının avlanması için toplam 39.251 sefer düzenlendiği kayıtlara geçmiştir (Anderson, 2009a: 125). 18. yüzyıl başlarında Ruslar kürk avc1lığ 1 için bölgeye yöneldiklerinde adalar civarında balina avcıllğı artık sona ermek üzeredir. Arktika'da yaşayan bir diğer önemli tür olan deniz ayıları ise çoğunlukla Beyaz Deniz kıyılarından gelen Rus yerleşimciler (Pomorlar) tarafından avlanmıştır. Rusların ardından Norveçliler de 19. yüzyılda kürk avcıllğı için Takımada'da varlık göstermiş, onların hedefinde ise Arktika tilkileri, foklar ve kutup ayıları yer almıstır (Anderson, 2009a: 127; Molenaar, 2012: 4).

Svalbard Takımadas1, keşfinden itibaren 20. yüzyıla kadar herhangi bir devletin egemenliği altına girmemiştir. Norveçliler, Ruslar, Hollandalılar, İngilizler ve İsveçliler bu süre zarfinda Takımada çevresindeki deniz alanlarında 'denizlerin serbestliği' (mare liberum - freedom of the seas) ${ }^{5}$ ilkesi temelinde ekonomik faaliyetlerini yürütmüsslerdir (Ingimundarson, 2018: 895). Yine de 1600 'lü y1lların başında Svalbard ve çevresindeki deniz alanları üzerinde başlayan bu faaliyetler ve sonrasında yapılan bilimsel araştırmalar, bu bölge üzerinde egemenlik ve sömürge yarışını başlatmıştır. Hollanda, Fransa ve İspanya, Hugo Grotius'un savunduğu mare liberum ilkesini esas alarak Takımada çevresindeki deniz alanlarında avlanma hakları olduğunu ileri sürmüşlerdir (Arlov, 2005: 9). Benzer tarihlerde Danimarka-Norveç, Britanya ve Çarlık Rusyası ise Takımada üzerinde egemenlik hakları olduğunu iddia etmişlerdir (Churchill ve Ulfstein, 2010: 552).

Ortaya atılan iddiaların diğer ülkeler tarafindan kabul edilmemesi sonucu 19. yüzyllda Svalbard'ın hukuki statüsü terra nullius (no man's land), yani 'hiç kimseye ait olmayan topraklar' olarak belirlenmiştir. Terra nullius statüsü ile, Avango ve Martin'in de (2006: 4) ifade ettiği üzere, kisitlama ve vergilendirme olmaksızın tüm ülkeler bu alandaki doğal kaynakları

\footnotetext{
5 Mare liberum ilkesi, Hugo Grotius'un 1609 yllinda yayımlanan "De jure prædæ commentarius" (Ganimet Hukuku Üzerine Yorum) adlı eserinde ortaya attığı bir uluslararası hukuk ilkesidir. Grotius bu ilke ile ulusların tüm denizler üzerinden özgürce geçebileceğini ilan etmiştir. Akten (2004: 41-42), "Türk Boğazları ve Gemilerin Geçiş Rejimi” adlı makalesinde mare liberum ilkesinin ortaya çıkıs nedenini şu şekilde açıklamıştır: "Grotius'u böylesi bir çalssmaya iten neden, 1601 ynlinda Birleşik. Doğu Hindistan kumpanyası donanmasinm Santa Catarina adh Portekiz, gemisine el koymasyla bukuk alanindaki gelisen uluslararasi olaylar olmustur. Felemenk Cumburiyeti, o dönemde Birleşik. Ispanya ve Portekiz. Krallğggyla barş̧̧ ilişkiler içindeydi. Ne var ki, Portekiz Kralluğ Doğu Hint Adalarina yönelik ticareti kendi tekelinde tutmak istiyordu. El konan geminin yükeülle birlikte savas ganimeti olarak satılmast üzerine geminin kumpanyasi 1604 yulnda Grotius'dan bu konuda bukuki görüs istedi. Hugo Grotius, Mare Liberum başlikl çalısmann da yer aldı̆ğ, uluslararası bukuk alannda adinn duyulmasina yol açan ünlü yapitında Portekižin Felemenklileri ticaret haklarndan yoksun bırakttğm ileri sürerek gemiye el konmasm savundu”. Açık denizlerin serbestliği, yüzylllar boyunca deniz hukukunun en temel doktrinlerinden biri olmuştur. İnsanlarda okyanus kaynaklarının tükenmez olduğuna dair inanışın hâkim olması bunun en önemli sebebidir (Magnusson, 2010: 3).
} 
işletebilme hakkı elde etmişlerdir. 1871 yılına kadar Svalbard'ın bu statüsüne yönelik herhangi bir itirazda bulunulmamıştır. O tarihlerde Norveç'le ortak monarka sahip olan İsveç, Takımada'da kendisine ait ama her iki ülke adına faaliyet gösterecek bir maden yerleşimi kurmayı planlamıştır. İsveç’in, Avrupalı devletlerin rızasıyla Svalbard'ın yönetimini elde etme hedefine, var olan yasal düzenin devamından yana olan Norveç karşı çıkmıştır. Rus İmparatorluğu da Svalbard'da kendi tarihi varlığını ve pay sahipliğini ileri sürerek İsveç'in önerisini reddetmiştir. 17. yüzylldan itibaren bölgede balina avc1lı̆̆1 yapan ve bilimsel keşiflere öncülük eden Britanya ise İsveç’in girişimine karşı resmi bir tutum benimsememiştir. Ancak Hollanda'nın da Rus İmparatorluğu'na destek vermesi sonucunda, İsveç Svalbard'da egemenlik elde etme planını terk etmek durumunda kalmıştır (Ingimundarson, 2018: 895).

20. yüzyılın ilk yıllarında önemi artan uluslararası kömür araştırmaları ve kullanımı, ülkelerin zengin kömür yataklarına sahip olan Svalbard Takımadası'yla da yakından ilgilenmesine neden olmuştur. Maden faaliyetlerinin hızlanmasıyla birlikte, hiç kimseye ait olmayan bu topraklara dünyanın dört bir yanından gelen insanlar yerleştikleri arazilere birer tabela iliştirerek mülkiyet iddia etmeye başlamışlardır. Konu ile ilgili en dikkat çekici gelişme ise Britanyalı, Norveçli ve Amerikalı girişimcilerin açtıkları büyük madenlerdir (Anderson, 2009a: 127). ${ }^{6}$ Kısa sürede İsveçli, Rus ve Hollandalı maden şirketleri de burada faaliyet göstermeye başlamışlardır. Bu gelişmeler sonucunda giderek artan ekonomik faaliyetler, Svalbard'ın uluslararası statüsü konusunu yeniden gündeme getirmiştir. Norveç ve İsveç çatışan taleplerin uzlaştırılarak, kanun ve düzenin sağlanması için bir örgüt kurulmasını önermiştir (Ingimundarson, 2018: 895). Bu süreçte Svalbard Takımadası'nın hızla artan ekonomik ve stratejik önemi nedeniyle bu alanda hangi ülkenin/ülkelerin egemenlik sahibi olacağı ve nasıl bir yönetim izleneceğine dair farklı görüşler ortaya çıkmıştır. 19. yüzyıldan itibaren önce avcılik ardından da madencilik faaliyetleri çerçevesinde Svalbard'da en çok varlık gösteren ülkenin Norveç olduğu ifade edilmiştir. İsveç ve diğer Avrupalı devletler de Svalbard'ın ekonomik potansiyeli ve doğal kaynakları nedeniyle Norveç'i izleyerek keşif faaliyetleri gerçekleştirmişlerdir. Dolayısıyla hem Takımada'nın uluslararası statüsü hem de birden fazla devletin bu bölgede tarihsel olarak çeşitli ekonomik faaliyetler sürdürmüş olmaları Svalbard için farklı bir yönetim modelini kaçınılmaz kılmıştır (Ingimundarson, 2018: 895).

Norveç, Svalbard üzerindeki doğal kaynakların akılcı kullanımını sağlayabilmek, Takımada'nın hukuki statüsü ile ilgili sorunlara ortak bir

6 Örneğin, günümüzde Svalbard'ın idari merkezi ve en önemli yerleşim birimi olan Longyearbyen (Longyear Kasabas1), 1906'da Amerikalı madenci John Longyear tarafindan kurulmuştur (Anderson, 2009a: 127). 
çözüm üretebilmek ve bu alanda yeni bir düzen kurabilmek amacıyla Belçika, Hollanda, Rus İmparatorluğu, İsveç, Britanya, Alman İmparatorluğu, Fransa ve Danimarka'ya konunun görüşülmesine ilişkin bir teklifte bulunmuştur (Churchill ve Ulfstein, 1992: 22). Bu teklif sonucunda 1907'te bir araya gelen İsveç, Rus İmparatorluğu ve Norveç, terra nullius statüsündeki bu alanın söz konusu üç ülkenin yönetiminde olmasını ('con-dominium' yani 'ülke üzerindeki birkaç devletin egemenliği') ve Takımada'nın idari kontrolünün de Antlaşma'ya imza atan devletlerden oluşan uluslararası bir komisyonun elinde bulunmasını önermişlerdir (Churchill ve Ulfstein, 1992: 22; Wolf, 2013: 7). Ancak teklif Alman İmparatorluğu ve ABD tarafindan reddedilmiştir (Wolf, 2013: 7).

Svalbard Takımadası'nın hukuki statüsüne yönelik tartışmaların uzun yıllar çözülememesi sonucu, 1910-1914 tarihleri arasında Oslo'da uluslararas1 bir konferans düzenlenmiş ve Svalbard Kongresi'nin bir taslağ1 oluşturulmuştur. Burada a) terra nullius'un Takımada için yapay bir statü olması; b) toplu teminat altında Takımada'nın askerden arındırılması ve tarafsızlaştırılması; c) Takımada'nın idari yönetimi için Norveç, İsveç ve Rus İmparatorluğu temsilcilerinden oluşan Svalbard Komisyonu'nun kurulması planlanmıştır (Singh ve Saguirian, 1993: 59-60). Ancak, Birinci Dünya Savaşı'nın başlamasıyla taslak karara bağlanamadan görüşmeler ertelenmiştir.

Uluslararası barış ve güvenliğin kurumsal yapılarla sağlanacağını ve korunacağını varsayan liberal ve idealist düşünceler savaş sonrası dönemde uluslararası alanda ön plana çıkmıştır (Ar1, 2014: 4). Bu dönemde Svalbard Takımadası'ndaki terra nullius statüsünün yaratmış olduğu anlaşmazlıklara barışçıl ve kalıcı bir çözüm getirilmesi de amaçlanmıştır. 1919 yılında düzenlenen Paris Barış Konferansı'nda, Svalbard Komisyonu kurulmuş ve Takımada'nın idari yönetiminin Norveç'e verilmesi kararlaştırılmıştır. Bu karar; Norveç'in y1llar boyunca Takımada üzerinde ekonomik faaliyetlere ve bilimsel araştırmalara devam etmesinin yanı sıra, Takımada'daki ABD çıkarlarının önceki önemini yitirmesi, İngilizlerin buradaki madencilik faaliyetlerinin Birinci Dünya Savaşı sırasında oldukça azalması ve Norveç'in savaş sırasındaki politik bağlantısızlı̆̆ı gibi bir dizi faktörle ilgili olmuştur (Grydehøj vd., 2012: 101; Ingimundarson, 2018: 908). Svalbard üzerinde egemenlik iddiasında bulunan Rusların 1917 tarihli Bolşevik devrimi ile başlayan bir iç savaşın içinde olması ve verilen karara büyük bir tepki veremeyeceğinin anlaşılması da bu kararın alınmasında etkili olan bir başka faktör olarak yorumlanabilir.

Sonuç olarak, dönemin beş büyük gücü (Fransa, İtalya, Japonya, Britanya ve ABD) Takımada üzerindeki haklarının (ekonomik ve bilimsel aktivitelerinin) korunması şartıyla, Norveç'in Svalbard üzerindeki idari yönetimini tanımayı kabul etmiştir. Buna göre 9 Şubat 1920'de imzalanan ve 
14 Ağustos 1925’te yürürlüğe giren Svalbard Antlaşması'yla Takımada'nın 'kendine özgü egemenliği’ Norveç'e verilmiştir.

\section{Svalbard Antlaşması}

Günümüzde 46 ülkenin taraf olduğ ${ }^{7}$ Svalbard Antlaşması ${ }^{8}$ ile Takımada'nın siyasi, ekonomik, ekolojik ve askeri durumu ile ilgili bir çerçeve çizilerek hukuki statüsü tanımlanmıştır. Buna göre Antlaşma, $10^{\circ}$ $35^{\circ}$ Doğu meridyenleri ve $74^{\circ}-81^{\circ}$ Kuzey paralelleri arasındaki 'büyük ya da küçük tüm adalar ve onlara ait kayalar' üzerinde Norveç'in 'tam ve mutlak egemenliğinin' (full and absolute sovereignty) olduğunu belirtmektedir (Madde 1). Ancak Norveç dişında, Antlaşma'yı imzalayan diğer ülkelerin de kendi vatandaşları ve şirketleri için mevcut rejimden hak kazanımları olmuştur. Buna göre tüm akit taraflar Takımada üzerindeki balıkçılık, avcılık, madencilik, endüstriyel ve ticari aktivitelerden, Takımada üzerinde ve çevresindeki deniz alanlarında yürütülen ekonomik faaliyetlerden muamele eşitliği ilkesi temelinde yararlanabileceklerdir (Madde 2 ve Madde 3). Churchill ve Ulfstein (2010: 571) bu ilkeyi, ekonomik faaliyetlerin sürdürülmesi için terra nullius rejimi altında akit tarafların haklarının korunması olarak yorumlamaktadır.

Svalbard Antlaşması, akit taraflara ait gemilerin ve vatandaşların madde 1'de belirtilen alanlarda balıkçılık ve avlanma konusunda eşit haklara sahip olduğunu belirtmektedir (Madde 2). Tüm akit tarafların vatandaşlarının yerel yönetmelik ve kurallara uyulması şartiyla Madde 1'de belirtilen alana ait sulara, fiyortlara ve limanlara ayrım gözetmeksizin erişim ve giriş özgürlüğü vardır ve vatandaşlar mutlak eşitlik ilkesi ile bu alandaki ticari aktivitelerine devam edebilmektedir (Madde 3). Bununla birlikte Norveç'in, gerekli görüldüğü takdirde, söz konusu alana ait fauna ve floranın korunması için uygun önlemler almak ve bu konuda karar vermekte serbest olduğu belirtilmektedir (Madde 2). Bununla ilgili herhangi bir k1sitlama yoktur. Ancak Svalbard sınırları içerisindeki özel bir alanın koruma altına alınması ve oradaki faaliyetlerin yasaklanması Norveç de dahil olmak üzere tüm devletler

\footnotetext{
7 Afganistan (1929), Arnavutluk (1930), Arjantin (1927), Avustralya (1923), Avusturya (1930), Belçika (1925), Bulgaristan (1925), Kanada (1923), Şili (1928), Çin (1925), Çek Cumhuriyeti (2006), Danimarka (1924), Dominik Cumhuriyeti (1927), Misır (1925), Estonya (1930), Finlandiya (1925), Fransa (1924), Almanya (1925), Yunanistan (1925), Macaristan (1927), İzlanda (1994), Hindistan (1923), İrlanda (1923), İtalya (1924), Japonya (1925), Letonya (2016), Litvanya (2013), Monako (1925), Hollanda (1920), Yeni Zelanda (1923), Kuzey Kore (2016), Norveç (1924), Polonya (1931), Portekiz (1927), Romanya (1925), Rusya (1935), Suudi Arabistan (1925), Slovakya (2017), Güney Afrika (1923), Güney Kore (2012), İspanya (1925), İsveç (1924), İsviçre (1925), Britanya (1923), ABD (1924), Venezuela (1928).

${ }^{8}$ Svalbard Antlaşması'nın tam metni için bkz. University of Oslo The Faculty of Law (t.y.). "The Svalbard Treaty", https://www.jus.uio.no/english/services/library/treaties/01/111/svalbard-treaty.xml (Erişim tarihi: 22.05.2019).
} 
için geçerli olacak, böyle bir durumda Norveç kendisi için öncelik talep edemeyecektir.

Madde 1'de belirtilen alanlar dahilinde kurulan veya kurulacak olan halka açık telsiz telgraf istasyonlarının tümü, tüm akit taraflara ait gemilerden ve vatandaşlarından gelen iletişimlere mutlak eşitlik ilkesiyle daima açık tutulacaktır. (Madde 4). Norveç egemenliği, mülkiyet hakkını Antlaşma’ya akit tarafların vatandaşlarına eşitlik ilkesine uygun olarak vermeyi, akit tarafların elde ettiği bu hakları korumayı taahhüt etmektedir (Madde 7). Antlaşma, akit taraflardan tahsis edilen vergilerin, harçların ve aidatların yalnizca Svalbard yönetimine tahsis edilmesini zorunlu hale getirmektedir (Madde 8). Ayrıca, Takımada'da katma değer vergisi ve devlet kazancını artırmaya yönelik başka vergilerin alınması tamamen yasaklanmaktadır (Madde 8). Norveç, yetkisini yalnızca Takımada'nın yönetimi için kullanabilmekte, bunun için ihtiyaç duyduğu miktarın dışında bir gelir elde edememektedir. Böylece, Norveç devletinin aşırı vergilendirme yoluyla Takımada üzerinden ekonomik avantaj elde etmesi engellenmiştir (Grydehøj, 2014: 46).

Antlaşma, Norveç ile Antlaşma'ya taraf diğer devletler arasında maden düzenlemelerinin iletişim kurularak benimsenmesine hükmeden bir prosedür içermektedir (Madde 8). Bunlara ek olarak, Svalbard Takımadası'nın savaş yanlısı amaçlar için kullanılmamasını taahhüt ederek Norveç'in Takımada üzerinde deniz üssü veya askeri tahkimat kurmasina izin vermemektedir (Madde 9). Bu sebeple, Takımada üzerinde Norveç’in, çoğunluğu sahil güvenlik kuvvetlerinden oluşan askeri varlığı belli belirsizdir. Churchill ve Ulfstein'a göre (2010: 557) bu hükmün iki amaca hizmet ettiği söylenebilir. Bunlardan ilki, Norveç'in Takımada üzerindeki kendine özgü egemenliğini kullanarak bu alandan stratejik olarak yararlanmasını engellemeye çalışmak, ikincisi ise Takımada'nın barışçıl kullanımının korunmasını sağlamaktadır.

\section{Svalbard Takımadası Çevresindeki Deniz Yetki Alanlarına Yönelik Tartışmalar}

Svalbard Antlaşması ile belirlenen akit tarafların haklarının kapsamı ve Norveç'in egemenlik hakkının kapsamı Takımada çevresindeki deniz alanlarına yönelik en önemli tartışma konusudur. Bu sorun esas olarak Svalbard Antlaşması'nın uluslararası deniz hukuku sözleşmelerinden daha önceki bir tarihte imzalanmış olmasından kaynaklanmaktadır. Svalbard Antlaşması'nın imzalandığ1 ve yürürlüğe girdiği tarihlerde münhasır ekonomik bölge ve kıta sahanlığı gibi kavramların tanımı kesin olarak yapılmamıştır. Buradan doğan boşluk, Norveç’in ve diğer akit tarafların Antlaşma’yı farklı şekillerde yorumlamalarına neden olmaktadır. Çalışmanın bu kısmında, uluslararası deniz hukuku sözleşmeleri ile uluslararası deniz hukuku kavramları haline gelen münhasır ekonomik bölge-balıkçılık koruma 
bölgesi ve kıta sahanlı̆̆ı kavramları Svalbard Takımadası özelinde değerlendirilmiştir.?

\subsection{Münhasır Ekonomik Bölge ve Balıkçılık Koruma Bölgesi}

Münhasır ekonomik bölge, Svalbard Antlaşması'nda yer almayan ve BMDHS ile uluslararası deniz hukuku literatürüne giren bir deniz alanı kavramıdır. Münhasır ekonomik bölge, karasularının ölçülmeye başlandığı esas hatlardan itibaren 200 deniz miline kadar uzanan bir alanı kapsamaktadır (BMDHS, Madde 57). Bu bölge sahildar devletin mutlak egemenliğinde değildir. Devlete yalnızca deniz yatağı üzerindeki sularda, deniz yataklarında ve bunların toprak altında canlı ve cansız doğal kaynakların araştırılması, işletilmesi ve muhafazası gibi bölgenin ekonomik amaçlarla araştırılması, kullanılması ve bilimsel araştırma yapılması konusunda yetki vermektedir (BMDHS, Madde 56).

Münhasır ekonomik bölge, sahildar devletlerin mutlak egemenliği altında olmadığ1 için BMDHS söz konusu bölge sınırları içerisinde bu devletlere kısıtlamalar getirmektedir. Buna göre, bölgeye kıyısı olan veya olmayan tüm devletlere seyrüsefer ile uçuş serbestliği ve denizaltı kabloları ile petrol boruları döşeme serbestliğinden yararlanabilme hakkı tanınmaktadır [BMDHS, Madde 58(1)]. Yani, sahildar devlet münhasir ekonomik bölge sınırları içerisinde kendisine tanınan hakları kullanırken diğer devletlerin hak ve yükümlülüklerini gerektiği şekilde göz önünde bulundurmakla görevlidir. Bununla birlikte diğer devletler de münhasır ekonomik bölge sinırları içerisinde BMDHS uyarınca haklarını kullanırken, sahildar devletin hak ve yükümlülüklerini göz önünde bulundurmalıdırlar [BMDHS, Madde 58(3)].

BMDHS, deniz alanının korunması konusunda çok sayıda hüküm içermektedir. Buna göre sahildar devletlere, münhasır ekonomik bölge sınırları içerisindeki alanlarda gemilerin sebep olduğu deniz kirliliğinin önlenmesi ve/veya azaltılması konusunda ayrımc1 olmayan yasa ve yönetmelikler uygulama hakkı tanımaktadır (Madde 192 ile Madde 236 arası). BMDHS münhasır ekonomik bölgenin aksine, balıkçılık koruma bölgesi gibi diğer fonksiyonel deniz bölgelerine ilişkin özel olarak kapsayıcı ifadelere yer vermemektedir. Devletlerin yetki ve sınırları genel hatlarıyla esas olarak 1958 tarihli Cenevre Sözleşmesi’ndeki Balıkçılık ve Açık Denizin Canlı Kaynaklarının Korunması Hakkındaki Sözleşme uyarınca belirlenmiştir. Buna göre: "Bir devletin karasularna bitisik olan açk deniz bölgelerindeki deniz. tabamma tespit edilen techizat vasitasiyla işletilen balikesulik sabalarmm (fisheries), o devlet tarafindan düzenlenebilmesi, o devlet vatandaşlarmm uzun zamandan beri bu

\footnotetext{
9 Münhasır ekonomik bölge-balıkçlık koruma bölgesi ya da kıta sahanlığı gibi deniz yetki alanlarının aksine, Svalbard Antlaşması'na taraf ülkeler arasında Takımada'nın karasularına yönelik hukuki bir anlaşmazlık bulunmamaktadır. Antlaşma'nın 2. ve 3. maddesinde karasularına ilişkin yetkiler ve sınırlandırmalar kesin bir dille ifade edilmiştir.
} 
bahkegullk sahalarm idame ettirmis olmalar ve isletmis olmalarna bağlıdır. Şu kadar ki, balıkçılğın uzun zamandan beri teamüle göre münhasiran vatandaşlar tarafindan yapılmıs olduğu sahalar dışında vatandas olmayanlar, vatandas olanlarla eşit şekilde bu faaliyetlere katılmaya mezundurlar" (Cin, 2006: 26-27).

Balıkçılık koruma bölgesinin karasuları ötesinde ve münhasır ekonomik bölge sınırları içerisinde özel bir deniz alanı olması nedeniyle sahildar devlet bu alan üzerinde sınırlı yetkilere sahiptir. Buna göre, sahildar devlet yalnızca belirli ekonomik ve koruyucu amaçlarla bu deniz alanı üzerinde yetkisini kullanabilmektedir. Norveç bu gelişmeler ışı̆̆ında, 3 Haziran 1977 tarihli Kraliyet Kararnamesi ile Svalbard Balıkçılık Koruma Bölgesi’ni kurmuştur. Balıkçılık Koruma Bölgesi'nin ilan edilmesi Norveç tarafindan iki temel amaç ile açıklanmaktadır. Takımada çevresindeki deniz alanları balık sahaları için Arktika Bölgesi'nin en verimli alanlarından biridir. O nedenle ilk olarak buradaki canlı kaynakların korunması ve bölgenin iyi yönetimi önemsenmiştir. Amaçlardan bir diğeri ise münhasır ekonomik bölge yerine koruma bölgesinin ilan edilmesi ile bölgedeki olası tartışmaları engelleme isteğidir (Pedersen, 2009: 150).

Norveç, Svalbard Antlaşması'nın karasuları ötesindeki deniz alanlarına yönelik herhangi bir hükmünün bulunmadığını, dolayısıyla mevcut bölgede Antlaşma'nın esas aldığı ayrımcılık yasağı ve muamele eşitliği ilkelerini ihlal etmediğini belirtmektedir (Holst, 1981: 83). Ancak Norveç'in uluslararas1 deniz hukuku sözleşmeleri uyarınca Antlaşma dahilinde olmayan bir deniz alanını ilan etmesi, diğer akit tarafların eleştirilerine neden olmuştur. Bunlar arasında en önemlisi Norveç'in yasal olarak balıkçılık koruma bölgesi kurma ve bu alan üzerinde yarg1 yetkisini kullanma hakkına sahip olmadığının savunulmasıdır. Öte yandan Norveç'in balıkçılık koruma bölgesi kurmasının yetki dahilinde olduğu ancak muamele eşitliği ve ayrımcllık yasağ1 ilkelerini esas alarak bu yetkiyi kullanabileceği de belirtilmektedir.

Burada ortaya atılan asıl soru şudur: Svalbard çevresindeki deniz alanlarında 1920 Antlaşması mı yoksa sonraki bir tarihte imzalanan BMDHS mi kabul edilmelidir? Bu soru hukuki tartışmaların öncelikli olarak lex priorlex posterior (önceki kanun-sonraki kanun) ilkesi çerçevesinde değerlendirilmesine neden olmaktadır. Viyana Antlaşmalar Hukuku Sözleşmesi (Vienna Convention on the Law of Treaties, 1969) konu ile ilgili şu hükme yer vermektedir: "Daha önceki bir antlassmanın bütün taraflar ayn zamanda sonraki antlasmaya da taraf olduğu, fakat önceki antlasma 59. maddeye göre sona erdirilmediği veya yürürlü̈ü̈ askiya alınmadĭg zaman, daha önceki antlasma sadece bükümlerinin sonraki antlaşmayla bağdasması ölçüsünde uygulanır." [Madde 30(3)]. Bu bilgiler ışı̆̆ında lex prior-lex posterior ilkesi eski ve yeni antlaşmalann ikisinde de yer alan aynı konu üzerinde, antlaşmalardaki konuların bağdaşması halinde uygulanabilmektedir. Böyle bir durumda sonraki antlaşma öncekinden üstün gelmektedir. Ancak balıkçılık koruma bölgesinin 
Svalbard Antlaşması'nda yer almaması bu ilkenin uygulanabilirliğini mümkün k1lmamaktadir (Wolf, 2013: 15).

Konuya ilişkin yapılan hukuki değerlendirmelerde öne sürülen argümanlardan biri de lex specialis (özel kanun) ilkesidir. Buna göre, Svalbard Antlaşması uluslararası deniz hukuku sözleşmelerinden daha özel olarak kabul edilmektedir. Takımada için Antlaşma'nın esas alınması gerektiğini savunan ülkelerin başında Rusya ve İspanya gelmektedir (Åtland, 2010: 283). Bununla birlikte, Takımada üzerindeki Norveç egemenliğinin Svalbard Antlaşması uyarınca sınırlı olması, yani hem coğrafi olarak hem de kapsam olarak bu egemenliğin kısıtlanması gerekmektedir. Bu egemenlik daha önce de ifade edildiği gibi yalnızca kara, karasuları, iç sular, fiyortlar ve limanları kapsamakta ve Norveç'e bir sahildar devlet olarak 200 deniz mili sinırları içinde balıkçılık koruma bölgesini ilan etme hakkı tanımamaktadır (Pedersen, 2006: 345; Köni, 2015: 312). Aksine, Svalbard karasular1 ötesindeki deniz alanları BMDHS uyarınca açık denizler olarak kabul edilmeli ve burada balık avlama serbestisi olmalıdır (Pedersen, 2008b: 246).

Svalbard Antlaşmasi'na taraf olan Polonya ve Macaristan da benzer şekilde, Antlaşma'nın 2. ve 3. maddesi ile sağlanan hakları tek taraflı değişikliklerle ihlal eden Norveç Kraliyet Kararnamesi'nin Svalbard Antlaşması ile uyumlu olmadığını savunmuştur (Pedersen, 2008b: 241). Buna göre Takımada çevresindeki deniz alanlarında balıkçılık aktiviteleri yalnızca uluslararasi rejimler vasitasiyla düzenlenebilmekte ya da bu alanda sınırlandırma/kısıtlama olmadan balıkçılığın serbest bir şekilde yapılması gerekmektedir.

Svalbard Balıkçılık Koruma Bölgesi'ndeki Norveç yetkisi, Antlaşma'ya taraf olan devletlerin büyük çoğunluğu tarafindan kabul edilmekte ve hukuka uygun bulunmaktadır. Ancak, Norveç'in Balıkçılık Koruma Bölgesi'ndeki egemenlik yetkisinin kabul edilmesi, bu ülkelerin Takımada çevresindeki deniz alanlarında ekonomik faaliyetlere yönelik eşit haklar elde etmesi ile ilişkilidir. Britanya, Almanya, Danimarka, Hollanda, ABD başta olmak üzere çoğu akit taraf, bu yetkiyi Antlaşma maddelerinde sılklikla yinelenen ayrımcılık yasağı ve muamele eşitliği ilkelerine bağlı kalınması halinde tanımaktadir.

Svalbard Antlaşması, akit taraflara hukuki olarak doğrudan ve/veya dolaylı yollardan ayrımcılık yapılmasını yasaklamaktadır. Ancak bu durum, bazı faaliyetlerin düzenlenemeyeceği anlamına gelmemektedir. Svalbard Antlaşması kapsamında Norveç gerekli durumlarda canlı ve cansız varlıkları korumak amacıyla bunlara yönelik ekonomik faaliyetleri düzenleme ve yasaklama hakkına sahiptir. Örneğin 19. yüzyılın sonlarında Svalbard'da yılda 400'den fazla kutup ay1s1 avlanmaktayken (Anderson, 2009a: 127), Norveç hükümeti günümüzde bu hayvanların korunması için son derece etkili yasal düzenlemeler hayata geçirmekte ve sıkı çevre koruma kuralları koymaktadır 
(Anderson, 2009b: 54; Koivurova, 2010: 28). Buna göre 2001 y1linda çıkarılan Svalbard Çevre Koruma Yasası ile Takımada'nın doğasının, yaban hayatının, flora ve faunasının, kültürel mirasının korunması hedeflenmiştir (Government of Norway, 2001). Kutup ay1ları gibi yasal olarak Svalbard'ın yerli (indigenous) türleri olarak kabul edilen, dolayısıyla Svalbard Çevre Yasası çerçevesinde ele alınan diğer deniz memelileri ise halkalı fok, liman foku, sakallı fok, mors ve belugadır. Bu türlere ilişkin uygulamalar ticari niteliğe sahip balıkçılık yasaları tarafından değil, Çevre Yasası kapsamında düzenlenmektedir. Svalbard Çevre Yasası'na göre halkalı fokların ve sakallı fokların avlanmasına belirli tarihlerde popülasyonlarını etkilemeyecek sayıda olmak üzere izin verilmiştir. Öte yandan Mink balinası ise bu sularda ticari olarak avlanmasina izin verilen tek balina türüdür (Norwegian Polar Institute, 2019).

ABD, Norveç'in Svalbard çevresindeki kaynakları yönetme ve koruma yetkisine itiraz etmemekte, ancak Antlaşma gereği akit tarafların bu kaynaklardan ekonomik olarak eşit koşullarda faydalanması gerektiğini belirtmektedir (Tiller ve Nyman, 2015: 147). Takımada çevresindeki deniz alanlarında Norveç'in kendine özgü egemenliğini kabul eden bir başka ülke olan Britanya, kaynakların doğru yönetiminde ve yasadışı balıkçılık ile mücadelede işbirliğine ihtiyaç olduğunu ve Norveç düzenlemelerinin Antlaşma'nın hükümleri ile tutarlı olduğu sürece, ayrımcılık yasağı ve muamele eşitliği ilkeleri çerçevesinde koruma bölgelerini desteklemekten kaçınmayacağını ifade etmektedir (Czarny, 2015: 223). Keşif yıllarından itibaren Takımada ile ilgilenen Hollanda da Antlaşma'da yer alan hükümlerin uygulanması halinde Balıkçılık Koruma Bölgesi'ni tanıyacağını belirtmekte ve Norveç'in kendine özgü bu egemenliğinin uluslararası hukuka aykırı bir yanının olmadığını savunmaktadır (Pedersen, 2008b: 242).

\subsection{Kita Sahanlı̆̆1}

Svalbard Antlaşması'ndan farklı olarak Cenevre Sözleşmesi ve BMDHS'de yer alan bir başka kavram kita sahanlığıdır. Kita sahanlığı kavramı 1940'lı yıllarda uluslararası alanda tartışma konusu olmaya başlamıştır. Teknolojik gelişmelerle birlikte, deniz yatağ1 altındaki kaynakların araştırılması ve kullanılması 20. yüzyılın ikinci yarısından itibaren daha önemli hale gelmiş ve böylece karasuları ötesindeki alanların da önemi artmaya başlamıştır. 'Uluslararası Hukuk Komisyonu'nun 1951 ynlındaki Ücüncü Oturumunda, kita sabanlĭ̆ işletilebilme esasi olarak, Bessinci Oturumda jeolojik unsurlarla 200 metre (veya 100 kulaç) derinliğe kadar olan deniz dibi ve bunun toprak alt olarak kabul edilmiş ve Komisyon'un 1956'da baẓrladiğ tasarida ise bu iki kistas birlestirilmiștir” (Meray, 1958: 84-85). Buna göre, kıta sahanlığ1 önce 200 metre derinliğe kadar, o derinlikten sonra ise suların işletmeye imkân verdiği yere kadar kabul edilmiştir (ILC, 1956: 296). 
1964 yılından itibaren geçerli olan 1958 tarihli Cenevre Sözleşmesi'nde sahildar devlet ile diğer devletlerin kıta sahanlı̆̆ına yönelik hakları açık bir şekilde belirtilmiştir (United Nations-Treaty Series, 1964: 312-320). Buna göre devletler, anakaradan deniz tabakasına uzanan alandaki kaynakları keşfetme ve araştırma hakkı elde etmişlerdir. Münhasır ekonomik bölge gibi kıta sahanlı̆̆ına yönelik yetki ve sinırlılıklar da BMDHS ile kesin olarak tanımlanmıştır. Sözleşme bu kavramın sınırlarını şu şekilde açıklanmaktadır: "Sahildar bir devletin kita sahanlĭgr, karasularmm ötesinde kita kenarmin dis eşĭgine kadar veya bu esilk daha az bir mesafede ise, karasularnm ölçülmeye baslandiğ esas hatlardan itibaren 200 deniz. mili mesafeye kadar olan kusimda, bu devletin kara ülkesinin doğal uzantısinn bütünündeki denizaltı alanlarmin deniz yată̆ ve toprak altlarm içerir." [BMDHS, Madde 76(1)].

Kıta sahanlığ1 üzerinde sahildar devletin haklanı ise şu şekilde açıklanmaktadır: "Sahildar devlet kita sahanliğr üzerinde arastırmada bulunmak ve buranı doğal kaynaklarm isletmek amaci ile egemen baklar kullanir. Sabildar devlet,

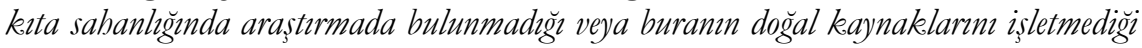
takdirde hic kimse, sabildar devletin açk rigası olmadan bu çessit faaliyetlere girişemez:" [BMDHS, Madde 77(1-2)]. Sahildar devletin, kıta sahanlığı üzerinde hak elde edebilmesi için Sözleşmeyi imzaladığı tarihten itibaren 10 yıl içerisinde Kıta Sahanlı̆̆1 Sinırları Komisyonu'na talepte bulunması gerekmektedir (BMDHS, Madde 312). Sözleşme uyarınca, Komisyon sahildar devletlere kıta sahanlığına ait dış sınırlarının tespitine ilişkin konularda tavsiyelerde bulunmakta ve bu tavsiyeler esas alınarak tespit edilen sinırlar kesin ve bağlayıcı olmaktadır [BMDHS, Madde 76(8)]. Deniz altındaki çıkıntılarının, kıta sahanlığının uzantısı olduğu jeomorfolojik kanıtlarla ispat edildiği takdirde, kıta sahanlığının dış sınırı karasularının ölçülmeye başlandığı esas hatlardan itibaren maksimum 350 deniz miline kadar çıarılabilmektedir [BMDHS, Madde 76(5-6)].

Kıta sahanlı̆̆1 ve münhasır ekonomik bölge, birbirine benzeyen ancak birbirinden farklı iki kavramdır. Sahildar devlet, kıta sahanlığ1 ile kendi karasularının ötesinde münhasır ekonomik bölge olarak bilinen özel denizcilik alanları oluşturabilmektedir (Brunet-Jailly, 2015: 815). Münhasır ekonomik bölgenin aksine, bir ülkenin kita sahanlığını ilan etmesine gerek yoktur. BMDHS, bu hakkın ab initio ve ipso facto olduğunu yani başlangiçtan beri kendiliğinden oluşan doğal bir durum olduğunu kabul etmektedir. [Madde 77(3)].

Norveç'in Svalbard'a yönelik kıta sahanlı̆̆ı doktrini 1950-1960'lı yıllarda, kıta sahanlığ1 kavramının ortaya çıktığ1 uluslararası çabaların bir sonucu olarak şekillenmiş ve kıta sahanlığının Norveç anakarasından Takımada'nın kuzeyine doğru uzandığı (yaklaşık $84.30^{\circ}$ Kuzey paraleli) belirtilmiştir (Dyndal, 2014: 84). 1974 y1lında ise Svalbard'in Norveç anakarasına bağlı olduğu Norveç tarafından resmi olarak ifade edilmiştir (Pedersen, 2008b: 
238). ${ }^{10}$ Norveç, başlangıçta Svalbard Takımadası'nın kendine ait bir kıta sahanlığının olmadığını, aksine Norveç kıta sahanlığının bir uzantısı olduğunu ileri sürmüştür. Daha sonra bu iddiasından vazgeçerek Svalbard'ın kendi kıta sahanlığının olduğunu kabul etmiş, ancak Takımada'nın Norveç'e ait olduğunu ve dolayısıyla kıta sahanlığının da onun bir parçası olduğunu belirtmiştir (Köni, 2015: 315).

Norveç'in, kıta sahanlı̆̆ üzerindeki bu iddiasını yasal olarak uygun bulan Fleischer (2007: 6), Svalbard Antlaşması'nda kıta sahanlığ ile ilgili bir kavramdan bahsedilmemesi nedeniyle, Antlaşma'nın karasuları ötesinde geçerli olmadığını iddia etmektedir. Ulfstein (1995: 423) ise Antlaşma'nın kıta sahanlığı ile ilgili herhangi bir sınırlandırma içermediğini, bu nedenle söz konusu deniz alanı için geçerli olmadığını savunmaktadır. Ancak Ulfstein, Svalbard Takımadası'nın Norveç anakarasının bir uzantısı olmadığını, aksine Takımada'nın kendine ait bir kıta sahanlığının olduğunu ve bu sahanlık üzerinde Norveç egemenliğinin uygulanabileceğini belirtmektedir.

Svalbard Antlaşması'nın Norveç tarafindan bu şekilde yorumlanması, Svalbard Balıkçlık Koruma Bölgesi dışında hem bölgesel hem de uluslararası alanda yeni bir tartışma konusu ortaya çıkarmıştır. Konu ile ilgili temel olarak iki farklı hukuki argüman vardır. Birincisi, bunun uluslararası hukuk normlarına tamamen aykırı bir karar olarak değerlendirilmesi; ikincisi ise bu kararın Antlaşma'nın hükümlerine aykırı olmadığı ancak Antlaşma'daki ayrımcılık yasağı ve muamele eşitlik ilkeleri esas alınarak uygulanabileceğinin belirtilmesidir. Balıkçılık Koruma Bölgesi'ne yönelik anlaşmazlıklardaki gibi burada da benzer bir durumun olduğu söylenebilir.

Rusya, SSCB döneminden itibaren Svalbard Balıkçllk Koruma Bölgesi'nde olduğu gibi, kıta sahanlığı konusunda da Norveç uygulamalarının uluslararası hukuka tamamen aykırı olduğunu savunan ülkelerin başında yer almaktadır. Konu ile ilgili resmi açıklama ilk kez Ağustos 1970'de yapılmış ve Norveç'in bu alan üzerinde herhangi bir yetkisinin olmadığı ifade edilmiştir. Bununla birlikte Takımada üzerindeki Norveç egemenliğinin teamül hukuku yerine kendine özgü uluslararası bir antlaşma üzerine kurulduğuna vurgu yapılmıştır (Østreng, 1984: 879). Burada ayrımcllık yasağı ve muamele eşitliği ilkeleri üzerinde önemle durulmaktadır. $\mathrm{Bu}$ ilkeler çerçevesinde, Norveç'in aldığı kararlar mevcut rejime aykırı bir girişim olarak görülmekte ve Antlaşma’nın ihlali olarak yorumlanmaktadır (Pedersen ve Henriksen, 2009: 144; Wolf, 2013: 21).

\footnotetext{
${ }^{10}$ Kıta sahanlığı sahildar devletlerin egemenlik alanlarını genişletebilmeleri açısından oldukça önemli bir kavramdır. Örneğin; denizaltındaki egemenlik alanı $235.000 \mathrm{~km}^{2}$ olan Norveç, uluslararası deniz hukuku uyarınca görülebilir kanıtlarla Komisyon'a başvurduğu takdirde bu egemenlik Norveç anakarasının 6 katı büyüklüğünde, yaklaşık 2 milyon $\mathrm{km}^{2}$ lik bir alanı kapsayabilecektir (Jensen ve Rottem, 2010: 77).
} 
ABD ve birçok Avrupa ülkesi, Antlaşma'nın 1. maddesinde belirtilen coğrafi alan içinde Norveç egemenliğini kabul etmekle birlikte, Norveç'in kıta sahanlı̆̆ı iddiasını tartışmaktadır (Brunet-Jailly, 2015: 812). Bu noktada Britanya, Norveç'in kıta sahanlı̆̆ı üzerinde hak iddia etmesini hukuka aykırı bir durum olarak değerlendirmemektedir. Ancak, Svalbard Antlaşması ile belirlenen rejime uygun olarak bu alan içinde akit tarafların da muamele eşitliği ve ayrımcılık yasağı ilkeleri temelinde hakları olduğunu belirtmektedir (Wolf, 2013: 17). İngiliz hükümetinin resmi görüşüne göre Svalbard Antlaşması'nın amacı, Takımada üzerinde ve çevresindeki deniz alanlarında akit tarafların ulusal çıkarlarını eşitlik ilkesi temelinde gözeten özel bir rejim sağlamaktır. Kendine özgü bir yapısı olan bu antlaşma, Norveç'in 'tam ve mutlak egemenliği' ile akit tarafların Takımada ve çevresindeki deniz alanlarına ayrımcılık yasağ1 ve muamele eşitliği ilkeleri temelinde erişim sağlamaları arasında bir denge gözetmeye çalışmaktadır (Fløistad, 2007: 37). Dolayısıyla Norveç kıta sahanlığı üzerinde egemenlik haklarını kullanacaksa, Antlaşma'ya taraf ülkelerin haklarının da ayrımcılık yasağı ve muamele eşitliği ilkelerine uygun olarak kıta sahanlığına kadar genişletilmesi gerekecektir (Dyndal, 2014: 85).

\section{Svalbard Takımadası Çevresindeki Deniz Alanlarında Norveç ve Diğer Aktörlerin Faaliyetleri}

Norveç tarafindan 1977 yılında ilan edilen Svalbard Balıkçılık Koruma Bölgesi hukuki sorunların yanı sıra politik tartışmaların da doğmasına neden olmuştur. Konuyla ilgili en önemli tartışmalardan biri, Balıkçılık Koruma Bölgesi'nde Antlaşma'ya taraf diğer ülkelerin gemilerine getirilen kota sınırlandırması ve Norveç Sahil Güvenliği’ne bu alanda yapılan yasadışı balıkçılı̆̆1 engellemek adına güç kullanma yetkisi vermesidir. 1977 Kararnamesi ile Balıkçılık Koruma Bölgesi'ne avlanma amacıyla gelen gemiler izin almak ve kayıt yaptırmak zorunda birakilırken, 1986 y1lında bazı türler için konulan kotalarla akit tarafların balıkçılık faaliyetleri sınırlandırılmıştır (Köni, 2015: 316). Bu kota uygulamaları, Takımada çevresindeki deniz alanlarında yapılan balıkçlık aktivitelerinin tarihsel geçmişi esas alınarak oluşturulmuştur. Geçmişten günümüze bu alanda balıkçılık faaliyetleriyle ilgilenen bazı ülkeler avlanma miktarı konusunda ayrıcalıklar elde etmişlerdir. Norveçli ve Rus balıkçılar Balıkçılık Koruma Bölgesi'ndeki balık kaynaklarında tarihsel olarak ana pay sahibi olurken, üçüncü ülkelere (AB üye ülkeleri ve Faroe Adaları) morina balığı ve deniz tabanındaki diğer canlı türleri için sınırlı sayıda kota tahsis edilmiştir (Misund vd., 2016: 1).

Ekonomisi büyük ölçüde balıkçılığa dayanan İzlanda'dan çok sayıda balıkçı, 1990’lı yıllarda morina balığının yoğun olduğu Svalbard çevresindeki deniz alanlarında avlanmaya başlamıştır (Perry ve Andersen, 2012: 47). Bunun üzerine dönemin Norveç Dişişleri Bakanı Bjoern Tore Godal ve 
Savunma Bakanı Jorgen Kosmo, İzlandalı balıkçı gemilerinin bu girişimlerini önlemek için gerekli her türlü önlemi alacaklarını duyurmuştur (Dunlap, 1997: 81). Balıkçılık Koruma Bölgesi'nde kota verilmemesine rağmen İzlanda'nın bu sularda avlanması Norveç tarafından Norveç balıkçılık mevzuatının ihlali olarak yorumlanmıştır (Fløistad, 2007: 39). İzlanda ise, Svalbard Antlaşması kapsamında İzlandalı balıkçı gemilerinin Takımada çevresindeki deniz alanlarında balıkçılık haklarına sahip olduklarını iddia etmeye devam etmiştir (Magnússon, 2010: 23). Kota engeline karşı geri adım atılmaması sonucunda, 1999 yilında imzalanan bir antlaşma ile İzlanda'ya balık kotası tahsis edilmiştir (Howard, 2009: 101). Bu antlaşma iki ülke arasındaki gerginliği azaltmış olsa da anlaşmazlıkların giderilmesi konusunda yetersiz kalmıştır. 2003 yılında İzlanda Başbakanı David Oddsson Svalbard Balıkçılık Koruma Bölgesi’nde ringa kotaları üzerindeki bir anlaşmazlığa istinaden Norveç Sahil Güvenliği'nin Takımada çevresinde ringa avlayan İzlandalı balıkçıları tutukladığı takdirde Uluslararası Adalet Divanı'na konu ile ilgili dava açacaklarını belirtmiştir (Howard, 2009: 209).

Daha önce de ifade edildiği gibi Rusya, Norveç'in Svalbard Balıkçılık Koruma Bölgesi üzerindeki idaresini resmi olarak tanımamıştır. Norveç’in Balıkçılık Koruma Bölgesi'ndeki balık kaynaklarında kendisi gibi ana pay sahibi olan Rus balıkçılara yasadışı avlanma gerekçesiyle yaptırımlarda bulunması iki ülke arasında gerginlik yaratmıştır. Gerilimi tırmandıran ilk olay, Norveç Sahil Güvenliği'nin Rusya bandıralı Novokuybyshevsk'teki balıkçıları 1998 yılında tutuklaması olmuştur. Hemen ardından 2001 yılında, başka Rus balıkçıları da balıkçılık düzenlemelerinin ihlali gerekçe gösterilerek Norveç Sahil Güvenliği tarafindan tutuklanmıştır (Perry ve Andersen, 2012: 57). Bunun üzerine Rusya Balıkçl11k Komitesi Başkanı, benzer bir durumun tekrar yaşanması halinde, Rus Kuzey Filosu'nun Norveç Sahil Güvenliğine ait gemilere ateş etmesi gerektiğini belirtmiştir (Korppoo vd., 2015: 98).

Rusya bu olayların ardından, Takımada çevresindeki deniz alanlarında balıkçılık haklarını korumak ve buradaki Norveç tutuklamalarını kontrol edebilmek için 2002 yaz aylarında Severomorsk isimli savaş gemisini Balıkçılık Koruma Bölgesi sinırları içine kısa süreliğine devriye amaçlı konuşlandırmıştır (Åtland ve Pedersen, 2008: 241). 2005 yılında ise yasadış1 balıkçılık yapıldığ1 gerekçe gösterilerek Elektron isimli başka bir Rus balıkçı gemisi Norveç tarafindan durdurulmuş ve denetlenmek istenmiştir. Ancak Elektron, Norveç denetiminden kaçarak Rus sularına yönelmiş ve Murmansk'a ulaşmıştır (Whist, 2008: 3).

Elektron olay1, o tarihlerde Rus-Norveç ilişkisindeki gerilimi artıran olaylardan biri olarak görülmüştür. Ancak, iki ülkenin olayın üzerine daha fazla düşmek istememesi nedeniyle, bir yıl gibi kısa bir sürede bu gerilim sona ermiştir. Norveç Dişişleri Bakanı Støre, Elektron meselesinin mantıklı bir şekilde çözüldüğünü ve bu olayın Rusya ile Norveç arasındaki 
çekişmenin bir konusu haline dönüşmediğini belirtmiştir (Norwegian Government Security and Service Organisation, 2005). Elektron olayinin diplomatik yollarla çözümü iki ülkenin konu ile ilgili tüm problemleri ortadan kaldırdığ1 anlamına gelmemektedir. Perry ve Andersen (2012: 44) barışçl yollarla çözüme kavuşan bu durumun, aslında potansiyel olarak devletler arasında ciddi bir diplomatik çatışmanın yaşanmasını kolaylaştırabileceğini ifade etmektedir. Nitekim Elektron olayından kısa bir süre sonra, 2008 yılında, Rusya bandıralı beş balıkçı gemisindeki ve Eylül 2011'de Sapphire II'deki balıkçılar aynı nedenler gerekçe gösterilerek Norveç Sahil Güvenliği tarafindan tutuklanmışır. $\mathrm{Bu}$ olayın ardından Rusya Balıkçlık Komitesi Başkanı "Rusya, Rus balıkçı gemilerini korumak için etkin tedbirler başlatmak istemektedir" diyerek Norveç denetimlerini kontrol edebilmek adına Balıkçılık Koruma Bölgesi'ne yeniden Rus gemileri konuşlandırılacağını ifade etmiştir (Chrášt’anský ve Kříz, 2011: 13).

Svalbard Balıkçlık Koruma Bölgesi'nde Norveç ile balıkçılık hakları konusunda anlaşmazlık yaşayan ülkelerden biri de İspanya'dır. İki ülke arasındaki anlaşmazlık, 1990'lı yılların ortasından itibaren İspanyol balıkçılarının eksik beyanları gerekçe gösterilerek, Balıkçlık Koruma Bölgesi'nde İspanyollara tahsis edilen kotaların Norveç tarafindan geri çekileceğinin belirtilmesi ile başlamıştır (Wolf, 2013: 25). 2004 yllında İspanyollara ait olan Olaberri ve Olazar gemilerine bu nedenle Norveç tarafindan el koyulmuştur (Pedersen, 2006: 349; Wolf, 2013: 26; Tiller ve Nyman, 2015: 143).

Bir başka İspanya bandıralı gemi olan Monte Meixueiro'daki balıkçılar da Norveç Sahil Güvenliği tarafından 2005 yllında tutuklanmıştır. İspanya'da tepki ile karşılanan Norveç uygulamaları AB Konseyi'nde gündeme getirilmiştir (Associated Press, 2005). Norveç ve İspanya arasındaki bu anlaşmazlık, $\mathrm{AB}$ Komisyonu'nun tartışmaya dahil olması nedeniyle iki ülke sınırlarını aşmıştır. Avrupa Birliği Svalbard Antlaşması'na taraf değildir. Ancak, Komisyon da İspanya gibi Norveç'in bu alandaki uygulamalarına endişeyle yaklaşmakta ve Antlaşma'nın akit tarafların Takımada çevresindeki deniz alanlarına girişlerini kısıtlamadığını ve Norveç'in yabancı gemilere bu nedenle el koyma yetkisine sahip olmadığını savunmaktadır (Wolf, 2013: 26). Takımada çevresindeki Norveç uygulamaları, Antlaşma'ya taraf diğer ülkelerde olduğu gibi Finlandiya'nın da konu ile ilgili görüşlerinde farklılıklar yaratmıştır. Finlandiya 1977 yılında Norveç’in Balıkçlık Koruma Bölgesi kararını destekleyici açıklamalar yaparken, zaman içerisinde Norveç'in muamele eşitliğini esas alan Svalbard Antlaşması'nı ihlal ettiğini dile getirmeye başlamıştır (Pedersen, 2008b: 251).

Şubat 2019'da Norveç Yüksek Mahkemesi, oybirliği ile aldığı kararla AB üyesi ülkelerin balıkçılarının Norveç'in kuzeyindeki sularda kar yengeci (snow crab) avlamak için Norveç’ten izin almaları gerektiğini ilan etmiştir. 
Norveç'in bu kararı diğer devletlerin Arktika'da petrol ve doğal gaz arama çalışmalarını sınırlandırmak için emsal olarak kullanabileceği yorumları yapılmıştır (Doyle ve Fouche, 2019). Yüksek Mahkemenin bu kararı, Norveç'in "Svalbard kıta sahanlığına ait deniz yatağında yer alan kaynakların çıkarılması için izin verme yetkisinin kendisine ait olduğu" yönündeki iddialarını destekler niteliktedir (McGwin, 2019). Bu karara neden olan gelişme, Ocak 2017'de Letonya bandıralı balıkçı teknesi Senator'ün mürettebat ve Rus kaptanının Svalbard Balıkçılık Koruma Bölgesi içinde yasa dışı kar yengeci avladıkları şüphesiyle Norveç Sahil Güvenlik güçleri tarafindan tutuklanmış olmalarıdır (Staalesen, 2017b). Svalbard Takımadaları konusunda uzman olan yazar Per-Arne Totland, kar yengecinin deniz dibinde yaşayan yerleşik bir tür (sedentary species) olması nedeniyle kıta sahanlığ1 düzenlemeleri içerisinde ele alındığını ifade etmektedir. Totland, aynı yasanın petrol ve doğal gaz için de uygulanabileceğini ileri sürmektedir (Staalesen, 2017a).

Daha önce de ifade edildiği gibi Norveç, ayrımcılık yasağı ve muamele eşitliği ilkeleri temeline oturtulan Svalbard Antlaşması'nın kıta sahanlı̆̆ı için geçerli olmadığını, bu alanla ilgili deniz hukuku sözleşmelerinin esas alınması gerektiğini iddia etmektedir. Takımada çevresindeki deniz alanlarında yer alan zengin petrol ve doğalgaz rezervleri bu iddianın ileri sürülmesindeki en önemli etken olarak görülmektedir. BMDHS sahildar devlete, kıta sahanlığ1 üzerinde araştırma yapma ve oradaki doğal kaynakları işletme amac1 ile egemen haklar vermektedir [Madde 77(1)]. Norveç de buna istinaden, 1960'l1 yılların ilk yarısında başladığı petrol arama faaliyetlerine Takımada'nın güney sınırında yer alan Barents Denizi'nde devam etmiştir. 1980'li yılların ortasında ise bu bölgede petrol endüstrisi için yeni bir keşif alanının açıldığını duyurmuştur. Ticari faaliyetler için açılan bu alan $74^{\circ} 30^{\prime}$ Kuzey koordinatlarında, yani Svalbard Antlaşması'nın 1. maddesinde belirtilen sınırların yaklaşık yarım derece içerisinde yer almaktadır (Pedersen, 2006: 347). Öte yandan Rus anonim şirketi MAGE'nin 1980-1988 yılları arasında, Svalbard çevresindeki sularda petrol aramak istemesi, kıta sahanlığ üzerinde yasadışı arama yapıldı̆̆ı gerekçe gösterilerek Norveç tarafindan kabul edilmemiştir (Pedersen, 2006: 348; Pedersen, 2008a: 917). Bu durum, ayrımcılık yasağı ve muamele eşitliği ilkelerinin Ruslar tarafindan bir kez daha sorgulanmasina neden olmuştur. Norveç 1989 yılında $74^{\circ}$ Kuzey enlemini kendi de dahil olmak üzere Antlaşma'ya taraf tüm ülkeler için araştırmaya veya kullanıma kapatmıştır (Pedersen, 2006: 347). Ancak Barents Denizi'nin kuzeyinde, Svalbard'ın doğu kısmında yer alan enerji kaynakları hakkında daha fazla bilgi edinebilmek amaciyla petrol arama faaliyetleri devam etmiştir (Wolf, 2013: 27).

Petrol başta olmak üzere fosil yakıtlar küresel ekonominin en yaygin kullanılan enerji kaynağıdır. Fosil yakıt kullanımının yol açtığı iklim 
değişikliğinin olumsuz etkileri giderek daha çok hissedilmektedir ${ }^{11}$; ancak dünya üzerinde farklı coğrafyalarda varlığı tespit edilen petrol yataklarına her geçen gün yenilerinin eklenmesi için devletler ve şirketler petrol arama faaliyetlerini sürdürmektedirler. 2015'te Norveç hükümeti, Svalbard'ın tartışmalı kıta sahanlığı da dahil olmak üzere bölgede petrol ve doğal gaz arama faaliyetleri için 23. izni vermişsir (Østhagen, 2018: 106). Norveç hükümetine bağlı Petrol Müdürlügü’nün internet sitesinde ülkenin petrol politikası ve kıta sahanlığ içerisinde gerçekleştirilen petrol arama faaliyetleri hakkında bilgiler yer almaktadır. Burada "Gelecek Kuzeyde" başığı alında Norveç'in henüz keşfedilmemiş petrol ve doğal gaz kaynaklarının yarısının Barents Denizi'nde, kalanının ise Norveç Denizi ile Kuzey Denizi'nde olduğu ifade edilmektedir (Norwegian Petroleum Directorate, 2019). Norveç söz konusu bölgede petrol arama ve çıkarma çalışmalarına büyük önem vermekte ve lisanslama çalışmalarına devam etmektedir.

\section{Sonuç Yerine Bir Değerlendirme ve Yeni Sorular}

Tiller ve Nyman'a göre (2015: 141) iklim değişikliğinin deniz kaynakları üzerindeki etkisi Arktika'da devletlerin siyasi çıkarlarını şekillendiren etmenlerden biridir. İklim değişikliği nedeniyle bölgedeki balık stoklarının yer değiştirmesi ve avlanma sahalarının giderek daha kuzeye kayması beklenmektedir. Arktika'da balıkçılık sahalarının devletlerin egemenlik alanlarının dışına doğru genişlemesi, bu bölgelerde potansiyel yeni kaynakların çıkartılması, turizmin gelişmesi, bu faaliyetler nedeniyle artan deniz trafiği giderek daha çok devletin bölgeye yönelmesine neden olmaktadır. Bu değisşimler Arktika'nın doğal, kültürel, ekonomik kaynaklarının sürdürülebilir yönetimi konusunda bölge ülkeleri için yeni zorluklar da yaratmaktadır. Bu nedenle Tiller ve Nyman (2015: 141), iklim değişikliğinin etkileri nedeniyle bölgede yeni ve eski kaynakların kullanımı konusunda ortaya çıkabilecek anlaşmazlıkların yönetilmesi için var olan idari rejimlerin ve anlaşmaların yenilenebileceğini, gerekirse yeni koşulların şekillendirdiği yeni yönetişim modellerinin oluşturulabileceğini ifade etmektedirler. Bu bağlamda yazarlar, 1977'den beri Svalbard bölgesinde çevre koruma hedefli bir rejim uygulayan Norveç hükümetinin, son yllarda

\footnotetext{
11 Arktika, iklim değişikliğinin etkilerinin en çarpıcı şekilde gözlemlendiği bölgelerden biridir. Buzulların erimesi, deniz seviyesinin yükselmesi gibi gelişmeler bölgedeki yerli halklar kadar kara ve deniz ekosistemlerini de olumsuz etkilemektedir. Öte yandan buzulların erimesiyle yeni deniz yollarının ortaya çıkışı, yeni çıkar çatışmalarına da neden olabilir. Bölgede özellikle balıkçlık ve petrol arama faaliyetlerinin arttırılması yönünde girişimler bir süredir hükümetlerin ve şirketlerin gündemini meşgul etmektedir. Konuyla ilgili ayrıntılı bilgi için bkz. Uysal Oğuz, C. ve Ersoy, G. (2016). "Kutuplardaki İklim Değişikliğinin Bölgesel ve Küresel Etkileri”. H. Gümrükçü, A. İnan Şimşek, G. Ersoy (Eds.), Küresel Bakışla Kutup Cağ̊ Farkel Disiplinler Cok Yönlü Perspektifler. Efil Yayınevi, Ankara, 157-170; Uysal Oğuz, C. (2017). "Inuit Halk1 ve İklim Değişikliğ̣’” H. Gümrükçü, G. Ersoy, A. İnan Şimşek, F. C. Yaşar Dinçer (Eds.), Küresel Bakışla Kutup Çăğ Taribi ve Hukuki Perspektif-Ekolojik Dönüşüm. Efil Yayınevi, Ankara, 111-131.
} 
bunu mülkiyet rejimine (property regime) dönüştürerek Svalbard Balıkçllık Koruma Bölgesi ilan etme girişimini irdelemektedirler.

Özellikle Arktika açık sularında petrol ve doğal gaz arama çalışmalarının artış1, Svalbard çevresine de dikkatleri çekmiştir. Norveç'in Balıkçılık Koruma Bölgesi çerçevesinde Svalbard çevresindeki sulara hâkim olması, Takımada'nın kıta sahanlığı ve dolayısıyla deniz yatağındaki mineraller üzerinde de hak iddia edebilmesi anlamına gelecektir. Svalbard açık deniz kaynaklarının çıkartılması ekonomik açıdan kârlı olursa, başta Rusya ve ABD olmak üzere birçok devlet, Norveç'in bu kaynaklar üzerinde yönetim ve düzenleme yetkisine sahip olmasına karşı çıkabilecektir. İklim değişikliği ve artan sıcaklıkların bölgedeki balık türleri ve miktarı üzerindeki etkisi de Svalbard çevresindeki statükoyu etkileyecek gelişmelerden biridir. Svalbard Anlaşması'na taraf ülkeler balıkçılık hakları ve kotalar hakkında yeni talepler gündeme getirebilirler (Tiller ve Nyman, 2015: 147).

Daha önce de ifade edildiği gibi Svalbard Antlaşması Madde 1'de belirtilen coğrafi alanda Norveç'e 'tam ve mutlak egemenlik' yetkisi vermektedir. Öte yandan Takımada'daki Norveç egemenliği Antlaşma'nın geri kalan maddelerinde belirtildiği gibi mutlak eşitlik ve ayrımcılık yasağı ilkeleri ile sınırlandırılmaktadır. Antlaşma bu bakımdan diğer uluslararası antlaşmalardan farklı olarak Norveç egemenliğinin 'kısmi egemenlik' ya da 'yar1-egemenlik' olarak adlandirılmasina neden olmaktadır. Bunun yanı sıra, Antlaşma'nın kapsamı dışında kalan deniz alanlarında sonraki tarihlerde imzalanan uluslararası deniz hukuku sözleşmeleri çerçevesinde Norveç'in yarg1 yetkilerini kullanma çabaları sorunun asıl kaynağını oluşturmaktadır.

Üzerinde tartış1lan sorular şu şekilde özetlenebilir: Norveç, BMDHS uyarınca Svalbard karasuları ötesinde yeni deniz alanları kurabilir mi ve/veya kendine ait kıta sahanlığı olduğunu iddia edebilir mi? $\mathrm{Bu}$ durum kabul edildiği takdirde, Antlaşma'nın en temel yapı taşı olan ayrımcılık yasağı ve eşitlik ilkeleri söz konusu alanlarda da uygulanabilir mi? Antlaşma'ya taraf ülkelerin Takımada çevresindeki deniz alanlarında sahip olduğu haklardan vazgeçmesi olası görünmemektedir. Norveç anakarasına bağlı bir sahanlık kurulduğu takdirde ve/veya Balıkçılık Koruma Bölgesi'nin ve seçilmiş bazı ülkelere dönük kota sınırlandırmalarının kabul edilmesi halinde, Antlaşma ile Norveç'e tanınan kendine özgü egemenliğin coğrafi kapsamı genişleyecek ve içeriği değiştirilmiş olacaktır. Norveç’in 1977 yılından itibaren aldığı kararlar, akit tarafların Antlaşma’ya olan bağll1ıklarını kuvvetlendirmektedir.

Öte yandan Svalbard Takımadası ve çevresindeki deniz alanları da dahil olmak üzere, Arktika'da iklim değişiklinin yol açtığı olumsuzlukların yanında deniz buzunun azalması ve buzulların erimesiyle yeni deniz yollarının ortaya çıkması, devletlerin ve şirketlerin bölgede petrol arama faaliyetleri, bölgeye yönelik siyasi ve ekonomik çıkarları öncelikli hale getirmektedir. Ancak kabul edilmelidir ki, Arktika dünyanın en hassas ekosistemlerinden birine sahiptir; 
bölgedeki ekonomik faaliyetlerin sürdürülemez niteliği küresel ölçekte geri dönüşü olmayan gelişmelere yol açmaktadır. Bu nedenle Svalbard Takımadası özelinde bu makalede ele alınan ekonomik çıkar çatışmaları ve deniz yetki alanlarına yönelik tartışmalar yerine, Anderson'un (2009b: 54) da vurguladığı gibi Arktika'da sorulması gereken asıl sorular, bu bölgenin iklim değişikliğinden ve yol açacağ tahribattan korunup korunamayacağ1, ortaya çıacak çatışmaların çözülüp çözülemeyeceği, hızlı şekilde kâr elde etmeyi hedefleyen şirketlerin ve hükümetlerin yol açabileceği yağmanın engellenip engellenemeyeceği, yaşam koşulları değişmekte olan yerli halklar için sürdürülebilir kalkınmanın sağlanıp sağlanamayacağıdır. $\mathrm{Bu}$ sorulara verilecek yanıtlar hem Arktika'nın hem de dünyanın geleceği açısından son derece önemli sonuçlar doğuracaktır. 


\section{Kaynakça}

Akten, N. (2004). “Türk Boğazları ve Gemilerin Geçiş Rejimi”. Milletlerarası Hukuk ve Milletlerarası Özel Hukuk Bülteni, 24(1-2): 33-40.

Anderson, A. (2009a). After the Ice: Life, Death, and Geopolitics in the New Arctic, Smithsonian Books, New York.

Anderson, A. (2009b). "The Great Melt: The Coming Transformation of the Arctic". World Policy Journal, Winter 2009/2010: 53-64.

Arctic Council (2018). "The Arctic Council: A backgrounder". https://arctic-council.org/index.php/en/about-us (erişim tarihi: 11.07.2019).

Arı, T. (2014). “Uluslararası İlişkilerde Büyük Tartışmalar ve Post-Modern Teoriler". T. Ar1 (Ed.), Uluslararası Iliş̧kiler Teorileri 2. Dora Basımevi, Bursa, 1-47.

Arlov, T. B. (2005). "The Discovery and Early Exploitation of Svalbard.Some Historiographical Notes”. Acta Borealia, 22(1): 3-19.

Associated Press (2005). "Norway Demands Nearly U.S. \$2 Million from Spanish Trawler for Illegal Fishing”. https:/ /www.enn.com/articles/3138-norway-demands-nearly-u.s.\$2-million-from-spanish-trawler-for-illegal-fishing (erişim tarihi: 10.06.2019).

Åtland, K. (2010). "Russia and its Neighbors: Military Power, Security Politics, and Interstate Relations in the Post-Cold War Arctic". Arctic Review on Law and Politics, 1(2): 279-298.

Åtland, K. ve Pedersen, T. (2008). "The Svalbard Archipelago in Russian Security Policy: Overcoming the Legacy of Fear - or Reproducing It?’. European Security, 17(2-3): 227-251.

Avango, D. ve Martin, P. (2006). "Introduction and Background". Industrial Heritage in the Arctic: Research and Training in Svalbard, http://www.svalbardarchaeology.org/reports/Sval_Report_2004_ web.pdf (erişim tarihi: 11.04.2019).

Birleşmiş Milletler Deniz Hukuku Sözleşmesi (1982). http://www.unicankara.org.tr/doc_pdf/denizhukuku.pdf (erişim tarihi: 25.05.2019).

Brunet-Jailly, E. (2015). Border Disputes: A Global Encyclopedia [3 volumes], http://publisher.abc-clio.com/9781610690249.

Chrášt'anský, F. ve Kříz, Z. (2011). "Perception of the Situation in the Arctic by Key Actors and the Possibility of Conflict Escalation". 
Defence and Strategy, 1: 5-21, doi:10.3849/1802-7199.11.2011.01.005021.

Churchill, R. ve Ulfstein, G. (1992). Marine Management in Disputes Areas The Case of Barents Sea, Routledge, New York.

Churchill, R. ve Ulfstein, G. (2010). “The Disputes Maritime Zones Around Svalbard", M. H., Nordquist, T. H., Heidar ve J. N., Moore (Eds.), Changes in the Artic Environment and the Law of the Sea. Martinus Nijhoff Publishers, Boston, 551-593.

CIA World Factbook (2019). "Svalbard". https://www.cia.gov/library/publications/the-worldfactbook/geos/sv.html (erişim tarihi: 10.06.2019).

Cin, T. (2006). "Devletlerarası Hukukta Balıkç1l1k”. Dokuг Eylül Üniversitesi Hukuk Fakültesi Dergisi, 8(1): 21-45.

Coates, K. ve Holroyd, C. (2017). "Non-Arctic States and Their Stake in Arctic Sustainability". K. Keil ve S. Knecht (Eds.), Governing Arctic Change: Global Perspectives. Palgrave MacMillan, 207-228.

Czarny, R. M. (2015). The High North Between Geography and Politics, Springer, İsviçre.

Doyle, A. ve Fouche, G. (2019). “Abide by the claw: Norway's Arctic snow crab ruling boosts claim to oil". Reuters, 14.02.2019, https://www.reuters.com/article/us-norway-eusnowcrab-idUSKCN1Q3115 (erişim tarihi: 25.05.2019).

Dunlap, W. V. (1997). "Straddling Stocks in the Barents Sea Loophole". Boundary \& Security Bulletin, 4(4): 79-91.

Dyndal, G. L. (2014). "'The Political Challenge to Petroleum Activity around Svalbard". The RUSI Journal, 159(2): 82-88, doi: 10.1080/03071847.2014.912810.

Fleischer, C. A. (2007). "The New International Law of the Sea and Svalbard". The Norwegian Academy of Science and Letters 150th Anniversary Symposium http://www.dnva.no/binfil/download.php?tid=27095 (erişim tarihi: 11.10 .2015$)$.

Fløistad, B. (2007). Controversy over the Legal Regime outside Svalbard's Territorial Waters. Yayımlanmamış Yüksek Lisans Tezi. University of Oslo, https://www.duo.uio.no/bitstream/handle/10852/21363/67953. pdf?sequence $=1$ (erişim tarihi: 12.04.2019).

Government of Norway (2001). Svalbard Environmental Protection Act. https://www.regjeringen.no/en/find-document/dep/KLD/acts- 
and-regulations/acts/svalbard-environmental-protectionact/id173945/ (erişim tarihi: 25.05.2019).

Grydehøj, A. (2014). “Informal Diplomacy in Norway's Svalbard Policy: The Intersection of Local Community Development and Arctic International Relations". Global Change, Peace and Security, 26(1): 4154.

Grydehøj, A., Grydehøj, A. ve Ackrén, M. (2012). "The Globalization of the Arctic: Negotiating Sovereignty and Building Communities in Svalbard, Norway". Island Studies Journal, 7(1): 99-118.

Holst, J. J. (1981). "Norway's Search for Nordpolitic”. Foreign Affairs, 60(1): 63-86.

Howard, R. (2009). The Arctic Gold Rush the New Race for Tomorrow's Natural Resources, Continuum, UK.

ILC (1956). Report of the International Law Commission to the General Assembly (Document A/3159). United Nations Publication. New York.

Ingimundarson, V. (2018). “The Geopolitics of the 'Future Return': Britain's Century-Long Challenges to Norway's Control over the Spitsbergen Archipelago". The International History Review, 40(4): 893-915, doi: 10.1080/07075332.2017.1345773.

Jensen, Ø. ve Rottem, S. V. (2010). "The politics of security and international law in Norway's Arctic waters". Polar Record, 46(236): 75-83, doi:10.1017/S0032247409990076.

Koivurova, T. (2010). "Environmental Protection in the Arctic and Antarctica". N. Loukacheva (Ed.), Polar Law Textbook. TemaNord, Kopenhag, 23-43.

Korppoo, A., Tynkkynen, N. ve Hønneland, G. (2015). Russia and the Politics of International Environmental Regimes: Environmental Encounters or Foreign Policy?, Edward Elgar, UK

Köni, H. (2015). “Svalbard Antlaşması ve Arktik Bölgeler”. E. Denk (Ed.), Prof. Dr. Hüseyin Pazarci'ya Armağan. Ankara Üniversitesi Yayınlar1, Ankara, 307-318.

Magnússon, B. M. (2010). The Loophole Dispute From an Icelandic Perspective. Working Paper 1-2010. Centre For Small State Studies Publication Series University of Iceland. Iceland.

McGwin, K. (2019). “Svalbard Treaty doesn't apply beyond coastal waters, signals Norwegian high-court ruling in snow crab case". The Arctic Today, 14.02.2019, https://www.arctictoday.com/svalbard-treaty- 
doesnt-apply-beyond-coastal-waters-signals-norwegian-high-courtruling-in-snow-crab-case/ (erişim tarihi: 25.05.2019).

Meray, S. L. (1958). "Kıta Sahanlığ1 Hakkında Cenevre Sözleşmesi”. SBF Dergisi, 13(4): 80-94.

Misund, O. A., Heggland, K., Skogseth, R., Falck, E., Gjøsæter, H., Sundet, J., Watne, J., ve Lønne, O. J. (2016). "Norwegian fisheries in the Svalbard zone since 1980. Regulations, profitability and warming waters affect landings". Polar Science, 30: 1-11, http://dx.doi.org/10.1016/j.polar.2016.02.001.

Molenaar, E. J. (2012). "Fisheries Regulation in the Maritime Zones of Svalbard". The International Journal of Marine and Coastal Law, 27(1): 3-58 doi: 10.1163/157180812X610541.

Norwegian Government Security and Service Organisation (2005). "Climate, Oceans and Policies Challenges for the 21st Century". https://www.regjeringen.no/no/aktuelt/climate-oceans-andpolicies-challenges-f/id273152/ (erişim tarihi: 10.04.2019).

Norwegian Ministry of Justice and Public Security (2016). Meld. St. 32 (2015-2016) Report to the Storting (white paper) Svalbard. https:/ /www.regjeringen.no/contentassets/379f96b0ed574503b47 765f0a15622ce/en-gb/pdfs/stm201520160032000engpdfs.pdf (erişim tarihi: 25.05.2019).

Norwegian Petroleum Directorate (2019). "The Future is in the North". https://www.npd.no/en/facts/news/general-news/2019/thefuture-is-in/(Erişim tarihi: 25.05.2019).

Norwegian Polar Institute (2019). "Fauna on Svalbard". https://www.npolar.no/en/themes/fauna-on-svalbard/ (erişim tarihi: 25.05 .2019$)$.

NSIDC (2019). "What is the Arctic?”. https://nsidc.org/cryosphere/arcticmeteorology/arctic.html (erişim tarihi: 11.07.2019).

Østhagen, A. (2018). "Managing Conflict at Sea: The Case of Norway and Russia in the Svalbard Zone". Arctic Review on Law and Politics, 9: 100-123. http://dx.doi.org/10.23865/arctic.v9.1084.

Østreng, W. (1984). "Soviet-Norwegian relations in the Arctic". International Journal, 39: 865-887.

Pedersen, T. (2006). "The Svalbard Continental Shelf Controversy: Legal Disputes and Political Rivalries”. Ocean Development \& International Law, 37: 229-258, https://doi.org/10.1080/00908320600800960. 
Pedersen, T. (2008a). "The constrained politics of the Svalbard offshore area". Marine Policy, 32: 913-919, doi: 10.1016/j.marpol.2008.01.006.

Pedersen, T. (2008b). "The Dynamics of Svalbard Diplomacy". Diplomacy and Statecraft, 19: 236-262, doi: 10.1080/09592290802096299.

Pedersen, T. (2009). "Denmark's Policies Toward the Svalbard Area", Ocean Development \& International Law, 40:319-332, doi: 10.1080/00908320903076904.

Pedersen, T. ve Henriksen, T. (2009). "Svalbard's Maritime Zones: The End of Legal Uncertainty?". The International Journal of Marine and Coastal Law, 24: 141-161, 10.1163/157180808X353920.

Perry, C. M. ve Andersen, B. (2012). New Strategic Dynamics in the Arctic Region Implication for National Security and International Collaboration. The Institute for Foreign Policy Analysis. ABD.

Singh, E. C. ve Saguirian, A. A. (1993). "The Svalbard Archipelago: The Role of Surrogate Negotiators". O. R. Young ve G. Osherenko (Eds.), Polar Politics Creating International Environmental Regimes. Cornell University Press, Ithaca and London, 56-95.

Spohr, A. P., Höring, J., Cerioli, L. G., Lersch, B. ve Soares, J. G. A. (2013). "The Militarization of the Arctic: Political, Economic and Climate Challenges". UFRGS Model United Nations Journal, 1: 11-70.

Staalesen, A. (2017a). "Snow crabs raise conflict potential around Svalbard". The Barents Observer, 23.01.2017, https://thebarentsobserver.com/en/arctic/2017/01/s now-crabs-raises-conflict-potential-svalbard (erişim tarihi: 25.05.2019).

Staalesen, A. (2017b). "Norway takes tough line against EU in Svalbard waters". The Barents Observer, 25.01.2017, https://thebarentsobserver.com/en/industry-andenergy/2017/01/norway-takes-tough-line-against-eu-svalbardwaters (erişim tarihi: 25.05.2019).

Tiller, R. ve Nyman, E. (2015). "Having the cake and eating it too: To manage or own the Svalbard Fisheries Protection Zone". Marine Policy, 60: 141-148, doi: 10.1016/j.marpol.2015.06.011.

Ulfstein, G. (1995). The Svalbard Treaty: from terra nullius to Norwegian sovereignty. Scandinavian University Press, Oslo.

United Nations-Treaty Series (1964). Convention on the Continental Shelf. Done at Geneva, on 29 April 1958. (No.7302). United Nations. 
University of Oslo The Faculty of Law (t.y.). "The Svalbard Treaty", https://www.jus.uio.no/english/services/library/treaties/01/111/svalbard-treaty.xml (Erişim tarihi: 22.05.2019).

Uysal Oğuz C., ve Ersoy, G. (2016). "Kutuplardaki İklim Değişikliğinin Bölgesel ve Küresel Etkileri’. H. Gümrükçü, A. İnan Şimşek, G. Ersoy (Eds.), Küresel Bakışla Kutup Cağı Farkli Disiplinler Cok Yönlü Perspektifler. Efil Yayınevi, Ankara, 157-170.

Uysal Oğuz, C. (2017). "Inuit Halkı ve İklim Değişikliğı̀”. H. Gümrükçü, G. Ersoy, A. İnan Șimşek, F. C. Yaşar Dinçer (Eds.), Küresel Bakışla Kutup Că̆r Taribi ve Hukuki Perspektif-Ekolojik Dönüsüm. Efil Yayınevi, Ankara, 111-131.

Vienna Convention on the Law of Treaties (1969). http://legal.un.org/ilc/texts/instruments/english/conventions/1_ 1_1969.pdf (erişim tarihi: 05.04.2019).

Whist, B. S. (2008). "Norway and Russia in the High North: Clash of perceptions". The Norwegian Atlantic Committee, Security Brief 1: $1-4$.

Wolf, S. (2013). Svalbard's Maritime Zones, their Status under International Law and Current and Future Disputes Scenarios. German Institute for International and Security Affairs. Berlin. 